\title{
ANALYSIS OF CORRELATION BETWEEN CONSUMPTION AND REVENUE IN RWANDAN ECONOMY (ECONOMETRIC APPROACH, PERIOD OF STUDY: 1980-2012).
}

\author{
HABYARIMANA CYPRIEN \\ Independent Institute of Lay Adventists of Kigali, Department of Economics, Po Box 6392
}

\begin{abstract}
.
This study was designed to make analysis of correlation between consumption and revenue in Rwandan Economy; but for having a deep analysis; other macroeconomic variables have been included such as: consumer price index and interest rate. Without a deep and safe analysis of the macroeconomic variables, our economy will not have a trend to follow.

The econometric approach has been used for dissecting those macroeconomic variables, and various tools have been applied for avoiding the problem of spurious, nonsense regression. After running the model, the different results have been shown. Considering the model as whole, the correlation is high, $\mathrm{R}^{2}$ is $98 \%$. The regression has provided the long-run relation between those macroeconomic variables, but the error correction model has not provided any information.

In a given country if the consumption is not managed and linked with its explanatory variables, the economy is not sustained, reason why the present research has been conducted for showing the correlation between those variables and consumption and then after, there are the proposed measures for a sustainable economy after interpreting the results found.
\end{abstract}

\section{АТЛАСНАЯ ИНФОРМАЦИОННАЯ СИСТЕМА РОССИЙСКО-УКРАИНСКОГО ПРИГРАНИЧЬЯ}

\author{
${ }^{1}$ В.А.Колосов, ${ }^{2}$ Л.Г.Руденко, ${ }^{3}$ В.С.Тикунов, \\ ${ }^{1}$ А.А. Гериен, ${ }^{3}$ Е.Д.Головина, ${ }^{1}$ М.В. Зотова, ${ }^{l}$ А.С. Себенцов \\ ${ }^{1}$ Институт Географии РАН, Лаборатория геополитических исследований. \\ Москва, Старомонетный пер., 29 \\ ${ }^{2}$ Институт Географии НАНУ, \\ Киев, Владимирская ул, 44 \\ ${ }^{3}$ Московский государственный университет имени М.В. Ломоносова \\ Географический факультет \\ Москва, Воробьевы горы, 1
}

\section{ATLAS INFORMATION SYSTEM OF RUSSIAN-UKRAINIAN BORDERLAND}

\author{
${ }^{I}$ V.A.Kolosov, ${ }^{2}$ L.G.Rudenko, ${ }^{3}$ V.S.Tikunov, \\ ${ }^{1}$ A.A.Gercen, ${ }^{3}$ E.D.Golovina, ${ }^{I}$ M.V.Zotova, ${ }^{1}$ A.S.Sebentsov. \\ ${ }^{I}$ Institute of Geography, Russian Academy of Sciences, Staromonrtny per, 29. Moscow. \\ ${ }^{2}$ Institute of Geography NASU \\ Kiev, Vladimirskaya st., 44 \\ ${ }^{3}$ M.V.Lomonosov Moscow State University, Geographical Faculty, \\ Vorob'evy Gory, 1 Moscow 119991 Russia
}

\footnotetext{
Abstract.

Ukraine and Russia are linked by a common centuries-old history. Our countries are faced against difficulties as the long-pending modernization of the economy and natural decline in the population, obsolescence of fixed funds and lack of investment, need for reorganization in social sphere, etc.
} 